\title{
Kompetensi Komunikasi Pimpinan Terhadap Kinerja Pegawai Di Kementerian Agama Kabupaten Nias Utara
}

\author{
Safnal Rasyad Kabu ${ }^{*}$, Rudianto ${ }^{2}$, Ribut Priadi ${ }^{3}$ \\ Program Studi Magister Ilmu Komunikasi Universitas Muhammadiyah Sumatera Utara, Indonesia \\ ${ }^{* 1}$ Koresponden : srasyadkabu15@gmail.com
}

\begin{abstract}
Abstrak
Kantor Kementerian Agama Kabupaten Nias Utara mempunyai tugas melaksanakan tugas dan fungsi Kementerian Agama dalam wilayah kabupaten/kota berdasarkan kebijakan Kepala Kantor Wilayah kementerian Agama Provinsi dan ketentuan perundang-undangan yang tercantum dalam Berita Negara Republik Indonesia No. 1736, 2015, perihal Peraturan Menteri Agama Republik Indonesia Nomor 66 Tahun 2015 tentang pembentukan, organisasi, dan tata kerja 33 (tiga puluh tiga) Kantor Kementerian Agama kabupaten/kota. Untuk menjalankan amanat tersebut, diperlukan adanya komunikasi yang baik antara pimpinan terhadap para pegawai untuk meningkatkan kinerja institusi secara keseluruhan.Penelitian ini menggunakan metode korelasional.Tehnik pengumpulan data dilakukan dengan survey dan penyebaran kuisioner. Populasi penelitian ini berjumlah 63 orang. Hasil penelitian menunjukkan bahwa kompetensi komunikasi pimpinan (X) memberikan pengaruh sebesar 70.7\% terhadap kinerja pegawai (Y) sedangkan 29.3\% merupakan pengaruh yang diberikan oleh faktor atau variabel lain yang tidak diteliti dalam penelitian ini. Penelitian ini menemukan bahwa kompetensi komunikasi pimpinan berpengaruh positif dan signifikan terhadap kinerja pegaw ai.
\end{abstract}

Kata kunci: Kompetensi, Komunikasi, Kementerian Agama, Nias Utara

\begin{abstract}
Ministry of Religion Affairs office of North Nias Regency has the task of carrying out the duties and functions of the Ministry of Religion within the district / city area based on the policy of the Head of the Regional Office of the Ministry of Religion Affairs of the Province and the statutory provisions, listed in State Gazette of the Republic of Indonesia No. 1736, 2015, concerning Regulation of the Minister of Religion of the Republic of Indonesia No. 66 Year 2015 concerning establishment, organization and work procedure of 33 (thirty-three) district / city Ministry of Religion Affairs Offices. To carry out this mandate, it is necessary to have good communication between the leadership of the employees to improve the overall performance of the institution. This research uses the correlational method. Data collection techniques are done by surveying and distributing questionnaires. The study population was 63 people. The results showed that the leadership competency $(X)$ gave an effect of $70.7 \%$ on employee performance $(Y)$ while $29.3 \%$ was an influence given by other factors or variables not examined in this study. This study found that leadership competence had a positive and significant effect on employee performance.
\end{abstract}

Keywords: Competence, Communication, Ministry of Religion, North Nias

\section{PENDAHULUAN}

Komunikasi merupakan bagian yang penting dalam kehidupan kerja, salah satunya bagi Kantor Kementerian Agama Kabupaten Nias Utara. Hal ini dikarenakan komunikasi yang tidak baik berdampak yang luas terhadap kehidupan organisasi, misalnya konflik antar pegawai, dan sebaliknya komunikasi yang baik mampu meningkatkan saling pengertian, kerjasama dan juga kepuasan kerja sekelompok sumber daya manusia dengan berbagai karakter. Sehingga, komunikasi yang terbuka harus dikembangkan dengan baik agar masing-masing pegawai dalam organisasi mengetahui tanggung jawab dan wewenang masing-masing. 

Hasil komunikasi yang baik akan berpengaruh terhadap kinerja organisasi merupakan gambaran tentang hasil kerja organisasi dalam mencapai tujuannya yang pasti mempengaruhi sumber daya organisasi tersebut. Sumber daya yang dimaksud dapat berupa fisik seperti sumber daya manusia maupun nonfisik seperti peraturan, informasi, dan kebijakan. Konsep kinerja organisasi juga menggambarkan bahwa setiap organisasi publik memberikan pelayanan kepada masyarakat dan dapat dilakukan pengukuran kinerjanya dengan menggunakan indikator-indikator kinerja yang ada untuk melihat apakah organisasi tersebut sudah melaksanakan tugasnya dengan baik dan untuk mengetahui tujuannya sudah tercapai atau belum.

Hal ini juga didukung oleh hasil observasi dan sejumlah wawancara awal yang tidak terstruktur dengan beberapa pegawai Kantor Kementerian Agama Kabupaten Nias Utara. Dimana pesan dari Kepala Kantor Kantor Kementerian Agama Kabupaten Nias Utara berupa perintah tertulis seringkali menimbulkan berbagai penafsiran sehingga para pegawai merasa tidak yakin terhadap pekerjaan yang dilakukannya. Selain itu, terjadi penyimpangan komunikasi dari atas ke bawah ketika penyampaian pesan berupa hasil rapat pimpinan yang berisi kebijakan organisasi. Dengan bentuk komunikasi yang dilakukan Kepala Kantor Kantor Kementerian Agama Kabupaten Nias Utara, para pegawai acap kali tidak merasa puas, sebab informasi yang didapat tidak lengkap dan para pegawai juga sungkan bahkan takut untuk menyakan kekurangan informasi yang mereka dapatkan. Komunikasi yang searah dan cenderung tertutup tersebut pada akhirnymenumbuhkan iklim komunikasi yang tidak baik sehingga menimbulkan kecurigaan dan ketidakpercayaan terhadap pimpinan mereka, dan sering menjadi sinis atau apatis terhadap kebijakan yang diambil.

\section{Komunikasi Organisasi}

Goldhaber sebagaimana dikutip Muhammad (2005: 67) dalam buku yang berjudul Komunikasi Organisasi menyatakan bahwa komunikasi organisasi sebagai proses menciptakan dan saling menukar pesan dalam satu jaringan hubungan yang saling tergantung satu sama lain untuk mengatasi lingkungan yang tidak pasti atau yang selalu berubah-ubah. Redding dan Sanborn dalam Muhammad (2005: 65) mengatakan bahwa komunikasi organisasi adalah pengiriman dan penerimaan informasi dalam organisasi yang kompleks. Yang termasuk dalam bidang ini adalah komunikasi internal, hubungan manusia, hubungan persatuan pengelola,komunikasi downward atau komunikasi dari atasan kepada bawahan, komunikasi upward atau komunikasi bawahan kepada atasan, komunikasi horizontal atau komunikasi dari orang - orang yang sama leve1/tingkatnya dan komunikasi evaluasi program.

Tubbs dan Moss (1996: 166) menyatakan ciri utama komunikasi organisasional adalah faktor-faktor struktural dalam organisasi yang mengharuskan para anggotaya bertindak sesuai dengan peranan yang diharapkan. Sementara itu Pace dan Faules (2005: 31-33) mengklasifikasikan komunikasi organisasi menjadi dua, yakni definisi fungsional dan definisi interpretative. Definisi fungsional komunikasi organisasi adalah sebagai pertunjukan dan penafsiran pesan di antara unit-unit komunikasi yang merupakan bagian dari suatu organisasi tertentu. Sedangkan definisi interpretative komunikasi organisasi cenderung menekankan kegiatan penanganan pesan yang terkandung dalam suatu batas organisasional (organization boundary). Jadi, perspektif interpretative menekankan peranan orang-orang dan proses dalam menciptakan makna.

Komunikasi dalam organisasi berfungsi mencapai tujuan dari sistem organisasi, sehingga fungsi dari komunikasi meliputi informasi mengenai pekerjaan, pemeliharaan, 
motivasi, integrasi, dan inovasi. Hal yang terpenting dalam komunikasi organisasi meliputi penciptaan pesan, penafsiran, dan koordinasi kegiatan anggota organisasi.

Bagaimana komunikasi berlangsung dalam organisasi dan apa maknanya bergantung pada konsepsi seseorang mengenai organisasi (Pace dan Faules, 2005: 34). Komunikasi di dalam organisasi memiliki beberapa tujuan (Udaya, 1997: 149-150), yaitu:

\section{Memberikan informasi}

Tujuan utama komunikasi adalah mengirimkan informasi dari seseorang kepada orang lain atau kelompok-kelompok ala mat komunikasi. Berbagai jenis informasi di organisasi disampaikan dalam bentuk kebijakan, peraturan-peraturan, dan perubahan-perubahan serta perkembangan dalam organisasi.

\section{Umpan balik}

Komunikasi umpan balik membantu usaha untuk langkah-langkah perbaikan, penyempurnaan dan penyesuaian yang dibutuhkan organisasi, serta memberikan motivasi.

\section{Pengendalian}

Sistem informasi manajemen dikenal sebagai suatu mekanisme pengendalian. Informasi diberikan untuk menjamin pelaksanaan rencana-rencana sesuai dengan tujuan.

\section{Pengaruh}

Informasi merupakan kekuasaan. Semakin tinggi tingkatan dalam manajemen semakin besar peranannya untuk da pat memengaruhi sesuatu.

\section{Memecahkan persoalan}

Komunikasi bertujuan untuk memecahkan persoalan yang terjadi didalam organisasi.

\section{Pengambilan keputusan}

Untuk mengambil suatu keputusan diperlukan beberapa macam komunikasi, misalnya pertukaran informasi, pendapat, dan alternatif lain yang ada.

\section{Mempermudah perubahan}

Komunikasi membantu mengetahui kesulitan dalam perencanaan perubahan dan dala m mengambil tindakan perbaikan.

\section{Pembentukan kelompok}

Komunikasi membantu dalam proses pembangunan dan pengembangan hubungan dalam organisasi.

\section{Menjaga pintu}

Komunikasi membantu dalam berhubungan dengan dunia luar atau para pihak diluar organisasi.

\section{Kompetensi Komunikasi}

Konsep kompetensi saat ini terus bergantung pada kriteria orisinil dari Spitzberg dan William Cupach (1984) dalam Payne (2005:63) mengemukakan bahwa kompetensi komunikasi mencakup hal-hal seperti pengetahuan tentang peran lingkungan (konteks) dalam mempengaruhi isi (konten) dan bentuk serta kualitas pesan komunikasi (misalnya, pengetahuan bahwa suatu topik mungkin layak dikomunikasikan kepada pendengar tertentu di lingkungan tertentu, tetapi mungkin tidak layak bagi pendengar dan lingkungan yang lain) serta ditambah dengan pengetahuan tentang tatacara perilaku nonverbal (misalnya, kepatutan sentuhan, suara yang keras, serta kedekatan fisik).

Hal-hal tersebut merupakan faktor penting dalam berkomunikasi dengan komunikan, dalam hal penelitian ini adalah bawahan, yang dapat membawa dampak pada perubahan perilaku yang berwujud kemampuan (kompetensi) yang meliputi pengetahuan, pemahaman, ketrampilan dan sikap dalam pembelajaran terkait ilmu tertentu yang 
dipelajari. Secara singkat, komunikasi yang dilakukan oleh seorang komunikator yang kompeten mencakup dua hal, yaitu: efektifitas dan kesesuaian.

Jablin dan Sias dalam Payne (2005) mendefinisikan kompetensi komunikasi sebagai sejumlah kemampuan, selanjutnya, disebut resources, yang dimiliki seorang komunikator untuk digunakan dalam proses komunikasi. Definisi ini merupakan pendekatan strategik, berorientasi tujuan terhadap kompetensi yang menekankan pengetahuan dan kemampuan. Harrold Lasswell (1984) dalam Mulyana (2011: 69) mendefinis ikan komunikator atau sering disebut juga sumber (source), pengirim (sender), penyandi (encoder), pembicara (speaker), atau originator adalah pihak yang berinisiatif atau mempunyai kebutuhan untuk berkomunikasi. Sumber boleh jadi seorang individu, kelompok, organisasi, perusahaan atau bahkan suatu negara. Sekalipun fungsinya sama yaitu sebagai pengirim pesan, sebetulnya masing-masing istilah itu memiliki ciri khas tersendiri, terutama tentang sumber.

Seorang sumber bisa jadi komunikator/pembicara. Sebaliknya, seorang komunikator/sumber tidak selalu sebagai sumber. Bisa jadi dia menjadi pelaksana (eksekutor) dari seorang sumber untuk menyampaikan pesan kepada khalayak ramai atau individu. Dalam penelitian ini yang dimaksud komunikator adalah pimpinan. Pimpinan menyampaikan pesan yang bersumber pada dirinya sendiri atau menyampaikan ulang pesan pimpinan di atasnya kepada pegawai di bawahnya. Kompetensi komunikasi atasan didekati dengan konstruk kompetensi komunikasi komunikator. Pola komunikasi atasan dan bawahan dipengaruhi oleh komunikasi antar pribadi dan komunikasi kelompok. Menurut Payne (2005) dimensi-dimensi dari kompetensi komunikasi adalah antara lain sebagai berikut:

1. Motivasi komunikasi sering kali terkait dengan kesediaan seseorang untuk mendekati atau menghindari interaksi dengan yang lain. Kebanyakan penelitian motivasi komunikasi masuk dalam kerangka karakteristik, ke jengahan seperti rasa takut komunikasi atau rasa malu (Richmond \& McCroskey, 1992). Skala motivasi dirancang untuk mengukur kesediaan seseorang untuk memperluas empati, mengatur interaksi, dan menyesuaikan komunikasi di dalam organisasi.

2. Pengetahuan komunikasi. Untuk membuat rencana tindakan, sering kali disebut sebagai skenario komunikasi (Berger, 1997 dalam Payne, 2005). Para komunikator yang kompeten memiliki pengetahuan prosedural untuk menyusun dan menjalankan skenario ini didalam situasi sosial yang berbeda dan harus memiliki kemampuan perseptif untuk "membaca" situasi sosial. Menurut Spitzberg dan Cupach (1984 dalam Payne, 2005), pengetahuan prosedural adalah "mengetahui baga imana bukan isi dari mengetahui bahwa atau mengetahui apa". Pengetahuan ini diraih melalui pendidikan, pengalaman, dan dengan pengamatan apa yang Pavitt dan Haight (1986 dalam Payne, 2005) sebut prototipe dari kompetensi interpersonal - sebuah role model, sekaligus mengetahui standar organisasi untuk komunikasi.

3. Ketrampilan komunikasi. Mencakup kinerja aktual dari perilaku. Hal ini sering kali merupakan bagian yang sulit bagi komunikator - mengubah motivasi dan rencana menjadi tindakan. Individu sering kali termotivasi untuk berkomunikasi dan memiliki pengetahuan, namun kurang ketrampilan dalam pengkomunikasiannya secara aktual. Banyak ukuran ketrampilan mencakup variabel-variabel terkait seperti orientasi lain, kejengahan sosial, keekspresifan, manajemen interaksi. Pendekatanpendekatan ketrampilan lain fokus pada kemampuan psikomotor, kemampuan seseorang untuk berbicara, mendengar, melihat dan mengungkapkan pesan secara non-verbal dalam situasi tertentu. Ketrampilan yang dibutuhkan oleh organisasi termasuk pembinaan hubungan, 
menyimak dan mengikuti instruksi, memberikan umpan balik, bertukar informasi, mencari umpan balik, dan penyelesaian masalah.

\section{Kine rja Pegawai}

Bernardin dan Russel (dalam Ruky, 2002: 15) memberikan pengertian atau kinerja sebagai berikut: "performance is defined as the record of outcomes produced on a specified job function or activity during time period". Prestasi atau kinerja adalah catatan tentang hasil-hasil yang diperoleh dari fungsi-fungsi pekerjaan tertentu atau kegiatan selama kurun waktu tertentu.

Secara umum kinerja (performance) didefinisikan sebagai tingkat keberhasilan seseorang dalam melaksanakan pekerjaannya. Kinerja pegawai adalah ukuran dari seberapa banyak mereka memberi kontribusi kepada organisasi, dalam hal ini perusahaan tempatnya bekerja. Perbaikan kinerja baik untuk individu maupun kelompok menjadi pusat perhatian dalam upaya meningkatkan performa organisasi secara umum (Mathis dan Jackson, 2002: 78). Hasibuan (2006:108) berpendapat bahwa ukuran ini adalah ukuran dari seberapa banyak mereka memberi kontribusi kepada organisasi tempatnya bekerja. Hasil dari kontribusi ini yang dinamakan dengan kinerja. Mathis dan Jackson (2002: 58) menyatakan bahwa kinerja (performance) pada dasarnya adalah tentang hal yang dilakukan atau tidak dilakukan oleh pegawai. Kinerja pegawai menurut menurut Bernardin (2003: 76) dapat diukur melalui elemen berikut:

\section{Kualitas}

Tingkat dimana hasil akivitas yang dilakukan mendekati sempurna dalam arti menyesuaikan cara-cara ideal dari penampilan aktivitas ataupun memenuhi tujuan yang diharapkan dari suatu aktivitas.

\section{Kuantitas}

Jumlah yang dihasilkan dinyatakan dalam istilah sejumlah unit, jumlah siklus aktivitas yang diselesaikan.

\section{Ketepatan Waktu}

Tingkat suatu aktivitas diselesaikan pada waktu awal yang diinginkan dilihat dari sudut koordinasi dengan hasil output serta memaksimalkan waktu yang tesedia untuk aktivitas yang lain.

\section{Efektivitas}

Tingkat pengguna sumber daya organisasi dengan maksud menaikkan keuntungan atau mengurangi kerugian dari setiap unit dalam pengguna sumber daya.

\section{Kemandirian}

Tingkat dimana seorang pegawai dapat melaksanakan fungsi kerjanya tanpa meminta bantuan, bimbingan dari pengawas atau meminta turut campurnya pengawas guna menghindari hasil yang merugikan.

\section{Komitmen Kerja}

Tingkat dimana pegawai mempunyai komitmen kerja dengan perusahaan dan tanggung jaw ab kerja dengan perusahaan.

Terdapat pula faktor-faktor yang mempengaruhi kinerja pegawai (Mangkunegara (2010:18) yaitu:

\section{Fak tor Kemampuan (Ability)}

Secara psikologis, kemampuan (ability) pegawai terdiri dari kemampuan potensi (IQ) dan kemampuan realita (pendidikan). Oleh karena itu pegawai perlu ditempatkan pada pekerjaan yang sesuai dengan keahliannya.

\section{Faktor Motivasi (Motivation)}

Motivasi terbentuk dari sikap (attitude) seorang pegawai dalam menghadapi situasi (situation) kerja. Motivasi merupakan kondisi yang menggerakkan diri pegawai terarah 
untuk mencapai tujuan kerja. Sikap mental merupakan kondisi mental yang mendorong seseorang untuk berusaha mencapai potensi kerja secara maksimal.

\section{Teori S-O-R}

Teori komunikasi yang mampu menjelaskan bagaimana kinerja individu (pegawai) tercipta adalah teori stimulus - organisme - respons (S-O-R Theory). Teori S$\mathrm{O}-\mathrm{R}$ menjelaskan bagaimana suatu rangsangan mendapatkan respon. Tingkat interaksi yang paling sederhana terjadi apabila seseorang me lakukan tindakan dan diberi respon oleh orang lain (Model Stimulus-Respon). Menurut model stimulus respons ini, efek yang ditimbulkan adalah reaksi khusus terhadap stimulus khusus sehingga seseorang dapat mengharapkan dan memperkirakan kesesuaian antara pesan dan reaksi komunikan. Jadi unsur-unsur dalam model ini adalah pesan (stimulus, S); komunikan (organism, O); Efek (Response, R). Teori ini mendasarkan pada asumsi bahwa penyebab terjadinya perubahan perilaku tergantung kepada kualitas rangsang (stimulus) yang berkomunikasi dengan organisme. Artinya, kualitas dari sumber komunikasi (sources), misalnya kredibilitas, kepemimpinan, gaya berbicara sangat menentukan keberhasilan perubahan perilaku seseorang, kelompok atau masyarakat.

Menurut teori ini, dampak atau pengaruh yang terjadi pada pihak penerima, pada dasarnya merupakan suatu reaksi tertentu dari stimulus tertentu. Dengan demikian besar kecilnya pengaruh serta dalam bentuk apa pengaruh tersebut terjadi, tergantung pada isi dan penyajian stimulus. Dalam teori S-O-R, pengaruh eksternal dapat menjadi stimulus dan memberikan rangsangan sehingga sikap dan tingkah laku seseorang berubah. Untuk keberhasilan dalam mengubah sikap maka komunikator perlu memberikan tambahan stimulus (penguatan) agar penerima berita mau mengubah sikap. (Gibson, 2004: 197)

Menurut Hovland (2007: 270) perlu penguatan dalam pemberian stimulus. Hal ini dapat dilakukan dalam barbagai cara seperti dengan pemberian imbalan atau hukuman (reward and punishment). Dengan cara demikian ini penerima informasi akan mempersepsikannya sebagai suatu arti yang bermanfaat bagi dirinya dan adanya sanksi jika hal ini dilakukan atau tidak. Dengan sendirinya penguatan ini harus dapat dimengerti, dan diterima sebagai hal yang mempunyai efek langsung terhadap sikap. Untuk tercapainya ini perlu cara penyampaian yang efektif dan efisien.

\section{METODE PENELITIAN}

Adapun metode yang peneliti gunakan dalam penelitian adalah metode kore lasional. Menurut Sugiyono (2012: 5) metode penelitian dapat diartikan sebagai cara ilmiah untuk mendapatkan data yang valid dengan tujuan dapat ditemukan, dikembangkan, dan dibuktikan, suatu pengetahuan tertentu sehingga pada gilirannya dapat digunakan untuk memahami, memecahkan dan mengantis ispasi masalah.Dengan metode ini peneliti bermaksud mengumpulkan data historis dan mengamati secara saksama mengenai aspek-aspek tertentu yang berkaitan dengan masalah yang sedang diteliti oleh peneliti sehingga akan memperoleh data-data yang dapat mendukung penyusunan laporan penelitian. Data-data yang diperoleh tersebut kemudian diproses dan dianalisi lebih lanjut dengan dasar teori yang telah dipelajari sehingga memperoleh gambaran mengenai objek tersebut dan dapat ditarik kesimpulan mengenai masalah yang dite liti.

\section{HASIL DAN PEMBAHASAN}

Berdasarkan data penelitian yang telah dikumpulkan, maka diperoleh data tentang responden penelitian yang terdiri dari: (1) Jenis Kelamin, (2) Usia (3) Pendidikan 
Terakhir, (4) Status Perkawinan, (5) Masa Kerja (6) Jabatan. Tabel 4.1 hingga tabel 4.6 menyajikan ringkasan demografi responden.

Tabel 1. Jenis Kelamin Responden

\begin{tabular}{|c|c|c|c|}
\hline No & Jenis Kelamin & Frekuensi & Persentase \\
\hline 1 & Laki-laki & 32 & $51,6 \%$ \\
\hline 2 & Perempuan & 30 & $48,4 \%$ \\
\hline & Jumlah & 62 & $100,0 \%$ \\
\hline
\end{tabular}

Sumber: Data primer, 2019 (data diolah)

Tabel 1 menunjukkan responden berjenis kelamin laki-laki sebanyak 32 orang (51.6\%), dan perempuan sebanyak 30 orang (48.4\%). Hal ini menunjukkan antara lakilaki dan perempuan memiliki peluang yang sama dalam interaksi komunikasi antara atasan dan bawahan.

Tabel 2. Usia Responden

\begin{tabular}{clrr}
\hline No & Usia & Frekuensi & Persentase \\
\hline 1 & 30-40 Tahun & 10 & $16,1 \%$ \\
\hline 2 & 41-50 Tahun & 19 & $30,7 \%$ \\
\hline 3 & Di atas 50 Tahun & 33 & $53,2 \%$ \\
\hline & Jumlah & 62 & $100,0 \%$ \\
\hline
\end{tabular}

Sumber: Data primer, 2019 (data diolah)

Tabel 2 menampilkan data usia responden dimana usia 30-40 tahun sebanyak 10 orang $(16,1 \%), 41-50$ tahun 19 orang $(30,7 \%)$, dan di atas 50 tahun 33 orang $(53,2 \%)$. Pegawai Kantor Kementerian Agama kabupaten Nias Utara terdri dari berbagai ragam tingkat usia dan lebih dominan berkisar di usia 50 tahun ke atas. Hal ini tentunya membutuhkan kompetensi komunikasi yang baik dan berbeda untuk setiap tingkat usia.

Tabel 3. Jenjang Pendidikan Responden

\begin{tabular}{rrrr}
\hline No & Pendidikan & Frekuensi & Persentase \\
\hline 1 & SLTA/Sederajat & 4 & $6,5 \%$ \\
\hline 2 & D3 & 1 & $1,6 \%$ \\
\hline 3 & S-1 & 52 & $83,9 \%$ \\
\hline 4 & S-2 & 5 & $8,0 \%$ \\
\hline & Jumlah & 62 & $100,0 \%$ \\
\hline
\end{tabular}

Sumber: Data primer, 2019 (data diolah)

Tabel 3 menampilkan jenjang pendidikan responden yang terdiri dari tingkat pendidikan SLTA/Sederajat sebanyak 4 orang (6,5\%), jenjang D3 sebanyak 1 orang $(1,6 \%)$, jenjang S-1 sebanyak 52 orang $(83,9 \%)$ dan jenjang S-2 sebanyak 5 orang $(8,0 \%) . J e n j a n g$ pendidikan sangat mempengaruhi sikap seseorang dalam berkomunikasi.Hal ini tentuya menuntut seorang pimpinan untuk memiliki kompetensi komunikasi yang lebih baik. 
DOI: $10.30596 /$ persepsi.v3i1.4370

Tabel 4. Status Perkawinan Responden

\begin{tabular}{ccrr}
\hline No & Status Perkawinan & Frekuensi & Persentase \\
\hline 1 & Kawin & 61 & $98,4 \%$ \\
\hline 2 & Tidak Kawin & 1 & $1,6 \%$ \\
\hline & Jumlah & 62 & $100,0 \%$ \\
\hline
\end{tabular}

Sumber: Data primer, 2019 (data diolah)

Tabel 4 menampilkan status perkawinan responden dengan rincian Kawin sebanyak 61 orang $(98,4 \%)$ dan Tidak Kawin sebanyak 1 orang $(1,6 \%)$. Seluruh pegawai Kantor Kementerian Agama kabupaten Nias Utara pada dasarnya berstatus Kawin, adapun satu orang Tidak Kawin adalah berstatus Duda.Interaksi dalam komunikasi di antara anak-anak, remaja dan dewasa serta telah menikah berbeda satu dengan lainnya.Komunikasi secara formal lebih dominan, hal ini tentu dituntut untuk memiliki kompetensi komunikasi yang baik.

Tabel 4. Masa Kerja Responden

\begin{tabular}{ccrr}
\hline No & Masa Kerja & Frekuensi & Persentase \\
\hline 1 & 1-5 Tahun & 1 & $1,6 \%$ \\
\hline 2 & 6-10 Tahun & 3 & $4,8 \%$ \\
\hline 3 & Di atas 10 Tahun & 58 & $93,5 \%$ \\
\hline \multicolumn{2}{r}{ Jumlah } & 62 & $100,0 \%$ \\
\hline
\end{tabular}

Sumber: Data primer, 2019 (data diolah)

Tabel 5 merupakan masa kerja pegawai dengan rincian masa kerja 1-5 tahun sebanyak 1 orang (1,6\%), 6-10 tahun sebanyak 3 orang $(4,8 \%)$, dan di atas 10 tahun sebanyak 58 orang $(93,5 \%)$.Rata-rata pegawai Kantor Kementerian Agama kabupaten Nias Utara memiliki masa kerja di atas 10 tahun.Pegawai dengan masa kerja lebih lama memiliki dominasi lebih besar di lingkungan pekerjaan.Berbeda dengan pimpinan yang tidak menetap pada satu tempat pada waktu yang lama.Kompetensi komunikasi sangat dibutuhkan agar sikap dominasi ini dapat di atasi dengan baik oleh pimpinan.

Tabel 5. Jenis Golongan Jabatan Responden

\begin{tabular}{ccrr}
\hline No & Jenis Golongan & Frekuensi & Persentase \\
\hline 1 & Fungs ional Tertentu & 53 & $85,5 \%$ \\
\hline 2 & Fungs ional Umum & 4 & $6,5 \%$ \\
\hline 3 & Struktural Eselon IV & 5 & $8,1 \%$ \\
\hline & Jumlah & 62 & $100,0 \%$ \\
\hline
\end{tabular}

Sumber: Data primer, 2019 (data diolah)

Tabel 6 menampilkan jenis golongan jabatan yang terdiri darijabatan fungsional tertentu sebanyak 53 orang $(85,5 \%)$, fungsional umum sebanyak 4 orang $(6,5 \%)$ dan struktural eselon IV sebanyak 5 orang $(8,1 \%)$.Hal ini memberikan gambaran bahwa Kantor Kementerian Agama kabupaten Nias Utara berada pada situasi di mana pimpinan lebih sering berkomunikasi dengan stafnya. Pimpinan harus memiliki kompetensi 
DOI: $10.30596 /$ persepsi.v3i1.4370

komunikasi yang baik dalam menyampaikan tujuan yang hendak dicapai guna meningkatkan kinerja para pegawainya

\section{Uji Korelasi}

Koefisien korelasi bermanfaat untuk mengukur kekuatan hubungan antara dua variabel dengan skala-skala tertentu. Dalam penelitian ini, hubungan yang dimaksud adalah hubungan antara kompetensi komunikasi pimpinan $(\mathrm{X})$ dengan kinerja pegawai (Y) yang diperoleh hasil kore lasi seperti pada Tabel 7:

Tabel 7. Korelasi

\begin{tabular}{|l|r|r|r|r|}
\hline Model & \multicolumn{1}{|c|}{ R } & R Square & \multicolumn{1}{|c|}{$\begin{array}{c}\text { Adjusted R } \\
\text { Square }\end{array}$} & \multicolumn{1}{c|}{$\begin{array}{c}\text { Std. Error of the } \\
\text { Estimate }\end{array}$} \\
\hline 1 & $.841^{\mathrm{a}}$ & .707 & .703 & 2.509 \\
\hline
\end{tabular}

a. Predictors: (Constant), Total Kompetensi Komunikasi Atasan

Tabel 7 di atas merupakan nilai koefisien korelasi (R) sebesar 0.841 yang diperoleh dari hasil pengujian data.Nilai tersebut termasuk dala m kategori hubungan yang "sangat kuat" karena berada pada interval korelasi antara "0.80-1.00".Hasil tersebut menunjukan bahwa terdapat hubungan yang sangat kuat antara kompetensi komunikasi pimpinan $(\mathrm{X})$ de ngan kinerja pegawai $(\mathrm{Y})$.

\section{Koefisien Determinasi}

Koefisien determinasi diartikan sebagai seberapa besar kemampuan variabel bebas memberikan peranan pada variabel terikatnya. Koefisien determinasi dihitung dengan mengkuadratkan koefisien korelasi $\left(\mathrm{R}^{2}\right)$. Dalam hal ini untuk mengetahui besarnya peranan yang diberikan oleh kompetensi komunikasi pimpinan $(\mathrm{X})$ terhadap kinerja pegawai (Y) diperoleh data hasil sebagai berikut pada Tabel 8:

Tabel 8. Koefisien Determinasi

\begin{tabular}{|l|r|r|r|r|}
\hline Model & \multicolumn{1}{|c|}{$\mathrm{R}$} & R Square & \multicolumn{1}{|c|}{$\begin{array}{c}\text { Adjusted R } \\
\text { Square }\end{array}$} & $\begin{array}{l}\text { Std. Error of the } \\
\text { Estimate }\end{array}$ \\
\hline 1 & $.841^{\mathrm{a}}$ & .707 & .703 & 2.509 \\
\hline
\end{tabular}

a. Predictors: (Constant), Total Kompetensi Komunikasi Atasan

Pada tabel 8 di atas, nilai koefisien determinasi yang diperoleh adalah 0.707 atau 70.7\%. Hasil tersebut menunjukan bahwa kompetensi komunikasi pimpinan (X) memberikan pengaruh sebesar 70,7\% terhadap kinerja pegawai (Y). Sedangkan sebanyak $29,3 \%$ merupakan peranan yang diberikan oleh faktor lain yang tidak diteliti dalam penelitian ini.

\section{Regresi Sederhana}

Dari Tabel 8 terlihat nilai estimasi regresi pada kolom (B) Unstandardized Coefficients, jika dibuat model regresi linier sederhana maka persamaannya sebagai berikut:

$$
\mathrm{Y}=10.538+0.067 \mathrm{X}
$$


Tabel 9. Regeresi

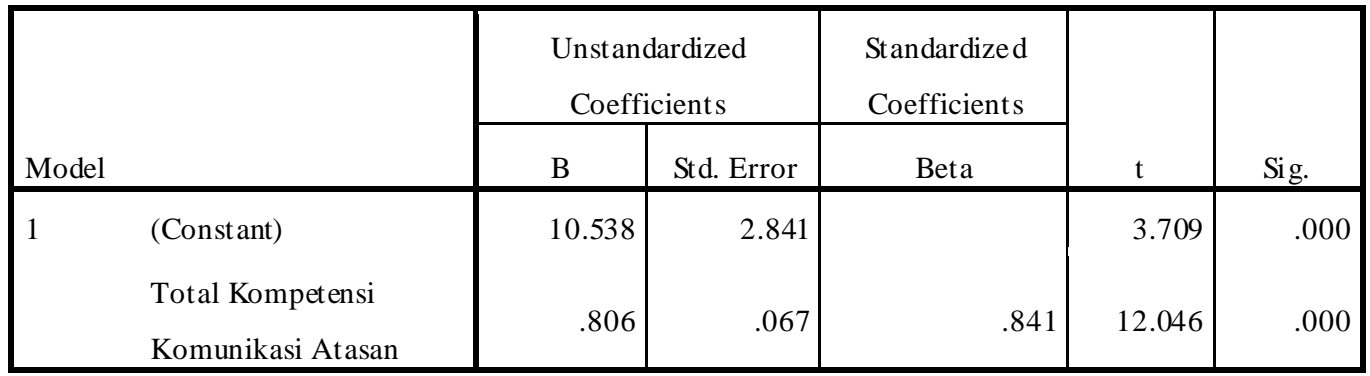

a. Dependent Variable: Total Kinerja Pegawai

Secara statistik, nilai yang tersaji pada persamaan re gresi linier sederhana Tabel 9 dapat diinterpretasikan sebagai berikut:

a. Nilai konstanta sebesar 10.538 menunjukan nilai kinerja pegawai (Y) jika kompetensi komunikasi pimpinan $(\mathrm{X})$ bernilai 0 .

b. Koefisien regresi untuk kinerja pegawai (Y) sebesar 0.067 dan bertanda positif yang menunjukan bahwa setiap terjadi kenaikan pada kompetensi komunikasi pimpinan $(\mathrm{X})$ sebesar satu satuan maka akan meningkatkan kinerja pegawai (Y) sebesar 0.067 satuan.

\section{Pengujian Hipotesis (Uji-t)}

Pengujian hipotesis dilakukan sabagai pembuktian apakah variabel kompetens $i$ komunikasi pimpinan $(\mathrm{X})$ memberikan peranan yang signifikan terhadap variabel kinerja pegawai (Y). Perumusan pengujian hipotesis (uji t) adalah sebagai berikut:

$\mathrm{H}_{0}: \beta=0$ Kompetensi komunikasi pimpinan $(\mathrm{X})$ tidak me mberikan peranan yang signifikan terhadap kinerja pegawai (Y).

$\mathrm{H}_{\mathrm{a}}: \beta \neq 0$ Kompetensi komunikasi pimpinan $(\mathrm{X})$ me mberikan peranan yang signifikan terhadap kinerja pegawai (Y). berikut:

Dalam menentukan kriteria pengambilan keputusan, dapat dikategorikam sebagai

- Tolak $\mathrm{H}_{0}$ dan terima $\mathrm{H}_{\mathrm{a}}$ jika nilai thitung >ttabel

- Terima $\mathrm{H}_{\mathrm{o}}$ dan tolak $\mathrm{H}_{\mathrm{a}}$ jika nilai thitung <ttabel

Taraf signifikansi yang digunakan ada lah sebesar 0,05 atau $5 \%$.

Menentukan nilai ttabel:

- Nilai ttabel didapat dari tabel distribusi $t$ pada taraf signifikansi $5 \%$.

- Nilai derajat bebas $(\mathrm{db})(\mathrm{n}(62)-\mathrm{k}(1)-1)$ sebesar 60 untuk pengujian dua pihak (two tailed) diperoleh nilai ttabel sebesar $\pm 2,048$.

Hasil pengujian disajikan pada tabel 10 di bawah ini: 


\section{Tabel 60. Pengujian Hipotesis (Uji-t)}

\begin{tabular}{|c|c|c|c|c|c|c|}
\hline \multicolumn{7}{|c|}{ Coefficients $^{a}$} \\
\hline \multirow{2}{*}{\multicolumn{2}{|c|}{ Model }} & \multicolumn{2}{|c|}{ Unstandardized Coefficients } & \multirow{2}{*}{$\begin{array}{c}\begin{array}{c}\text { Standardized } \\
\text { Coefficients }\end{array} \\
\text { Beta }\end{array}$} & \multirow[b]{2}{*}{$t$} & \multirow[b]{2}{*}{ Sig. } \\
\hline & & $B$ & Std. Error & & & \\
\hline 1 & (Constant) & 10.538 & 2.841 & & 3.709 & .000 \\
\hline & $\begin{array}{l}\text { Total Kompetensi } \\
\text { Komunikasi Atasan }\end{array}$ & .806 & .067 & .841 & 12.046 & .000 \\
\hline
\end{tabular}

a. Dependent Variable: Total Kinerja Pegawai

Nilai thitung (12.046) yang diperoleh variabel kompetensi komunikasi pimpinan (X) lebih besar dari nilai ttabel (1.990) sehingga menolak $\mathrm{H}_{0}$ dan menerima $\mathrm{H}_{2}$. Dari hasil tersebut menunjukan bahwa kompetensi komunikasipimpinan $(\mathrm{X})$ memberikan pengaruh yang signifikan terhadap kinerja pegawai (Y).

\section{SIMPULAN}

Berdasarkan hasil analis is dan pembahasan yang telah diuraikan pada bab sebelumnya dapat disimpulkan bahwa:

1. Hipotesa $\mathrm{H}_{1}$ dterima dimana kompetensi komunikasi pimpinan mempengaruhi kinerja pegawai pada Kantor Kementerian Agama Kabupaten Nias Utara, Provins i Sumatera Utara.

2. Kompetensi komunikasi pimpinan memberi peranan yang siginifikan terhadap kinerja pegawai Kantor Kementerian Agama Kabupaten Nias Utara.

3. Terdapat hubungan yang sangat kuat antara kompetensi komunikasi pimpinan dengan kinerja pegawai, hal ini sesuai dengan nilai koefisien relasi (R) sebesar 0.841 yang diperoleh dari hasil pengujian data. Nilai tersebut termasuk dalam kategori hubungan yang sangat kuat karena berada pada interval korelasi antara $0.80-1.00$.

4. Kompetensi komunikasi pimpinan memberikan pengaruh sebesar $70,7 \%$ terhadap kinerja pegawai. Sedangkan $29,3 \%$ merupakan peranan yang diberikan ole h faktor lain yang tidak diteliti dalam penelitian ini.

\section{DAFTAR PUSTAKA}

Bernardin, H., J. (2003). Human resources management: An experiential approach $\left(3^{\text {rd }}\right.$ ed.). New York, NY: Mc Graw-Hill/Irwin.

Gibson, S., K. (2004). Social learning (cognitive) theory and implications for human resource development. Advances in Developing Human Resources, 6(2), 193-210.

Hasibuan, M. (2006). Manajemen dasar, pengertian dan masalah. Jakarta: Bumi Aksara. Hovland, C., L. (2007). Definisi komunikasi. Jakarta: PT. Raja Grafindo Persada.

Mangkune gara. (2010). Evaluasi kinerja SDM. Bandung: PT Refika Aditama.

Mathis, R L., \& John H., J. (2002). Manajemen sumber daya manusia. Jakarta: Salemba Empat.

Muhammad, A. (2005). Komunikasi organisasi. Jakarta: Bumi Aksara.

Mulyana, D. (2011).Ilmu komunikasi. Bandung: PT. Rosdakarya.

Pace, R.W., dan Faules, D., F. (2005). Komunikasi organisasi: Strategi meningkatkan kinerja perusahaan. Bandung: Remaja Rosdakarya. 
PERSEPSI: Communication Journal

Vol 3No. 1, 2020, 12-23

e-ISSN 2623-2669

DOI: $10.30596 /$ persepsi.v3i1.4370

Payne, H., J. (2005). Reconceptualizing social skills in organizations: Exploring the relationship between communication competence, job performance, and supervisory roles. Journal of Leadership \& Organizational Studies, 11(2), 63-77.

Ruky, A.S. (2002). Sistem manajemen kinerja. Jakarta: Gramedia Pustaka Utama

Sugiyono.(2012). Metodologi penelitian pendidikan pendekatan kuantitatif, kualitatif dan $R \& D$. Bandung: Alfabeta.

Tubbs, S., L. dan Moss, S.(1996). Human communication (2 $2^{\text {nd }}$ d.). New York: Random House.

Udaya, Y. (1997). Pengantar ilmu manajemen. Jakarta: PT Gramedia Pustaka Utama. 